United States

David Dickson reports from the annual conference of the American Association for the Advancement of Science in San Francisco

\title{
Council supports arms control
}

FOLLOWING a public meeting at which a number of scientists described the increasingly urgent need to limit the proliferation of nuclear weapons, the council of the American Association for the Advancement of Science agreed last week to establish a working group "to help organise and mobilise resources towards nuclear arms control."

The AAAS council also agreed that efforts for directing science towards peace rather than war should be a major theme of next year's annual meeting, which will take place in Toronto.

Both decisions formed part of a resolution on nuclear weapons control submitted by seventeen members of the association, which pointed out that "improving the effectiveness of science in the promotion of human welfare is an objective and a special responsibility of the

\section{AAAS."}

By adopting the resolution, the AAAS council agreed to support both US efforts to obtain effective bilateral nuclear arms limitations and the completion of the

\section{Gene resource programme called for}

In a further resolution, the AAAS council gave its support to efforts to develop a national gene resource conservation programme. A resolution was passed which argued that there is insufficient support in the US for addressing the rapid depletion of germplasm resources of natural ecosystems, and that there is currently no comprehensive or effective national programme which would ensure that important germplasm resources are safeguarded.
Comprehensive Test Ban Treaty. It also expressed opposition to "the development by any country of new weapons systems which make verification more difficult, or pose a first-strike threat."

Supporters of the resolution point out that the latter is an implicit reference to, among other things, the recent decision by President Carter to recommend the deployment of a new generation of Minuteman missile, the MX.

The council also agreed to support the development of plans for the step-by-step conversion by all nuclear-weaponsproducing nations of facilities for nuclear weapons production, research and testing, into science and technology facilities for peaceful uses. Such "conversion" plans are expected to be made the subject of a special session at next year's meeting of the association.

\section{Military support of basic research defended}

RECENT increases in military support for basic research are rekindling the fierce debate over its social and ethical implications dormant for much of the past decade following widespread criticism during the Vietnam war era.

Supporters of military funding for science, addressing a session of the AAAS meeting, not only emphasised its importance for the long-term development of new weapons systems, but also claimed that through technological spin-offs which have ranged from synthetic rubber to large-scale integrated circuits military-supported research can help stimulate general industrial innovation in the US.

Critics, however, argued that the military control of research meant such research would inevitably be skewed towards the production of weapons of mass destruction, and was therefore in fundamental conflict with the well-being of mankind.

Dr George Gamota, director for research in the office of the UnderSecretary of Defense for Research and Engineering, told the audience that the department was trying hard to repair the working relationship with the scientific and engineering communities that had been weakened in the mid-1960s and early 1970 s.

Particular emphasis was being paid to restoring defense support for university research. Forty per cent of the basic research currently funded by DoD was carried out by universities; and over the past three years, university support increased by nearly $70 \%$, although overall support for basic research increased by only $30 \%$.

The need for military support for basic science, said Dr Gamota, "is rendered even more urgent by the relative decline in the extent of basic research conducted internally by industry or supported by the industrial sector on the academic community."

Referring to the Mansfield Amendment, passed in 1971 and restricting DoD support to research with a potential relationship to military needs, Dr Gamota said there was nothing in the act which touched upon the department's ability to support basic research. "Only the availability of funding and the level of interest of other agencies determines how wide a spectrum of research support is possible in the context of the DoD mission," he said.

Dr Gamota argued that it was impossible to single out any major basic research effort, particularly a new field, that could be categorically ruled out as potentially irrelevant to the Defense Department. "Our job is to follow the national trend and ensure that adequate funding is provided in areas of potential interest to DoD, and primarily only funding limitations and the extent of other agency interests limit our scope". The aim and goal of the department's support of basic research was "to ensure that the support will keep us technologically ahead of the world."

A full-blooded attack on such thinking, however, came from Professor George
Wald, emeritus professor of biology at Harvard University, who accused military planners of helping create a "mad nightmare of a world in which we are putting our children."

In contrast to those who argued that the US was now lagging behind the USSR in military technology, Professor Wald said that America was still five years ahead, both qualititatively and quantiatatively. And although he admitted that he had no confidence in the peaceful intentions of the Soviet Union, it was the US, he said, which was currently leading the arms race.

Earlier in the conference, Professor Philip Morrison of the Massachusetts Institute of Technology, argued that through a mixture of judiciously chosen policies it should be possible to cut the military budget by $40 \%$ to $50 \%$ while preserving the same level of national security as exists at present.

"The key point is to buy what we need, and organise to use it as we need. We need not buy systems because one or another service or firm wants us to do so, or because once in another world they were useful, or because the Soviet or someone else has them," Professor Morrison said.

Recent events at the global and domestic level made it important that scientists in the AAAS and elsewhere take a close look at science in the service of war. "The US has largely paced the arms race," he said. "We can cut military research and development to a reasonable size, and restore the talent and resources thus set free to the growing needs of civil society." 